\title{
DEONTOLOGIA PROFESJONALNEGO DZIALANIA W ZAWODACH POMOCOWYCH W ŚWIETLE ANALIZY KODEKSÓW ETYCZNYCH
}

\begin{abstract}
Abstrakt. Helping professions, zawody zaufania publicznego to niewątpliwie materia wyjątkowa i skomplikowana ze względu na doniosłość realizowanych potrzeb i interesów drugiego człowieka - klienta, beneficjenta, ucznia, pacjenta. Wydaje się, iż z ogromną odpowiedzialnością wiąże się objęcie pewnego rodzaju opieką i pomocą podmiotu, który jest słabszy i tym samym narażony na daleko idące konsekwencje w postaci podwójnego wykluczenia społecznego w przypadku podjęcia niewłaściwych działań pomocowych.

Prezentowany artykuł wpisuje się w aktualną, społecznie ważną interdyscyplinarną dyskusję o deontologii profesjonalnego pomagania. Przedstawiona analiza wybranych kodeksów etycznych dostarcza wiedzy na temat wspólnych cech czy też podstaw aksjologicznych w zawodach pomocowych, a w konsekwencji wskazuje na obowiązki etyczno-moralne łączące osoby zaufania publicznego w ich codziennych działaniach.
\end{abstract}

Slowa kluczowe: zawody pomocowe, kodeks etyczny, deontologia pomagania.

\section{Wprowadzenie}

Analizy kodeksów etycznych mieszczą się w obszarze badan socjologii pracy oraz filozofii deontologicznej. Deontologia to jeden z działów etyki, która to z kolei jest jednym z działów filozofii. Etyka traktuje o moralności sensu largo. Deontologia zaś jest nauką o obowiązkach i powinnościach moralnych sensu stricto. Sam termin „,deontologia” pojawił się w literaturze filozoficznej w 1834 roku dzięki pracy Deontology or the science of morality J. Benthama, który dał w niej wykład ogólnej teorii moralności, opartej na zasadzie tzw. rachunku szczęścia, czyli takiego postępowania, które przyczynia się do stwarzania maksymalnej sumy szczęściotwórczych przyjemności dla jak największej liczby ludzi. To Kantowi

* Mgr, doktorantka, Katedra Socjologii Stosowanej i Pracy Socjalnej, Instytut Socjologii, Wydział Ekonomiczno-Socjologiczny, Uniwersytet Łódzki, ul. Rewolucji 1905 r. 41/43, 90-214 Łódź, e-mail: bwodo@nieruchomoscidom.com 
jednak twórcy „imperatywu kategorycznego"1 przypisuje się nadanie temu pojęciu zabarwienia na wskroś powinnościowego (od sumy szczęść Benthama do maksymy Kanta postępowania takiego, by stało się ono prawem powszechnym [Kant 2010]). Jeśli jednak kierować się znaczeniem słowa „deontologia”, gdzie deon z greckiego oznacza „powinność, obowiązek”, to należy uznać, że deontologię wypełnia etyka Kanta, a nie Benthama (Ślipko 2004). Etyka deontologiczna oparta jest na poczuciu obowiązku, słuszności albo prawa, zgodnie z tym czyn jest etycznie dobry, jeśli stanowi wypełnienie obowiązku, prawa (Blackburn 1997). Deontologią nazywa się zbiór zasad etycznych regulujących obowiązki w pewnej szczególnej dziedzinie działalności, głównie związanej z zawodem, mówimy zatem przykładowo o deontologii lekarza, mediatora czy polityka (Blackburn 1997).

Kodeksy deontologiczne oprócz dostarczania - praktykującym te zawody, ale i podmiotowi pośredniemu, jakim są odbiorcy ich działania - zbioru norm, akceptowanych zachowań moralnych, są również źródłem ich poznania. Uwrażliwiają na przedmiot pracy, ujawniają skalę zobowiązań, jakie biorą na siebie jej wykonawcy. Wpływają na stan wiedzy, pokazują możliwe zagrożenia, pełnią funkcję informacyjną, ale i edukacyjną, mówiąc „,co wolno”, „co muszę”, „co jest zakazane”, a nawet „kto jest ważniejszy lub najważniejszy”2. W wymiarze filozoficznym kodeksy utrwalają etos zawodu, bo kojarzone są z zawodami zaufania publicznego, pokazują granice moralne, których profesjonalista nie powinien przekraczać (Zacharzewski 2011: 38). Z punktu widzenia psychologii społecznej dają przekonanie o dużej doniosłości nawet tych zawodów, które przez społeczeństwo nie są tak postrzegane, jak chcieliby tego sami profesjonaliści, podnoszą opinie i oceny ich dotyczące. Są zatem niezwykle istotne w kształtowaniu etyki zawodowej, bo jak pisał Zenon Klemensiewicz „każdy zawód wymaga od jego wykonawców określonych cech, określonego postępowania, zalet i cnót. Zachowanie zgodne z tymi wymaganiami określa się mianem etyki zawodowej" (Klemensiewicz 1968). Pojęcia „etyka zawodowa” i „deontologia” czy „kodeks deontologiczny” używane są współcześnie zamiennie, jako synonimy. Nie należy natomiast pominąć podstawowej różnicy między nimi; deontologia zawiera się w etyce zawodowej, gdyż dotyczy wybranej części etyki zawodowej dotyczącej powinności i obowiązku, a etyka zawodowa jest częścią etyki powszechnej i stanowi zespół bardziej specjalnych norm i zobowiązań, których wymaga się od osób pełniących określone funkcje zawodowe (Zacharzews si 2010).

Kodeks etyczny w swoich założeniach jest zaleceniem, a nie sankcją. Brak kar czy też odpowiedzialności, jednocześnie dobrowolny status, dobrowolne stanowienie i przestrzeganie - czy to stawia go wyżej czy niżej w hierarchii ważności

${ }^{1}$ „Postępuj tylko według takiej maksymy, dzięki której możesz zarazem chcieć, żeby stała się ona powszechnym prawem".

2 Dotyczy mediacji rodzinnych, w których podmiotem sporu jest dziecko (regulowane są sprawy z nim związane), to ono jest najważniejsze w tym procesie, a nie strony sporu (rodzice czy opiekunowie prawni), ani też mediator, który tutaj występuje w roli adwokata dziecka. 
dokumentów quasi-prawnych? Społeczeństwo ma możliwość kontrolowania określonych podmiotów ze względu na przyjęte kryteria, lecz jedyne „sankcje”, jakie może wywołać nieprzestrzeganie przyjętych zasad, to postawienie przed branżową komisją odpowiedzialności zawodowej, co może np. doprowadzić do wykluczenia zawodowego, lecz bardziej na skutek ostracyzmu aniżeli poniesienia wymiernej odpowiedzialności. Istnieją również branżowe kodeksy zawodowe, utworzone na podstawie ustawowego odesłania, i te w swojej istocie moga np. pozbawiać prawa do wykonywania zawodu czy też powodować wydalenie ze służby. Są to już daleko posunięte działania zmierzające w kierunku włączenia takiego kodeksu do kanonu obowiązującego prawa, gdyż i cechy upodobniające normy etyki do przepisów prawa, i ich powstanie następuje na podstawie wyraźnego upoważnienia zawartego w przepisie ustawowym (Ła bieniec 2002: 29). Nawet Trybunał Konstytucyjny w swym postępowaniu z 1992 roku uznał, że kodeksy deontologiczne same w sobie nie mają charakteru prawnego. Należą bowiem do niezależnego od prawa zbioru norm etycznych, a etyka nie wymaga legitymacji legislacyjnej.

\section{Profesjonalizacja zawodów pomocowych a rozwój kodeksów zawodowych}

Zdaniem Jerzego Szmagalskiego (1994), do głównych cech profesjonalizmu należy zaliczyć wysoki poziom i określony zakres wiedzy:

- dysponowanie sankcją społeczną dla wykonywania danej pracy,

- wysoki poziom samokontroli poprzez internalizację kodeksu etycznego w toku specjalizacji zawodowych (Grudziewska, Lewicka-Zelent 2015).

Wiliam E. Wickenden, dokonując charakterystyki profesjonalizacji zawodów społecznych, w których zawierają się helping professions, wyróżnił następujące ich cechy:

- rodzaj działalności, który wymaga dużej odpowiedzialności, a także stosowania specyficznych umiejętności rozwiązywania problemów na płaszczyźnie czysto intelektualnej,

- motyw służebności, który oznacza umiarkowane wynagrodzenie, rozumiane odmiennie niż zysk,

- motyw autoekspresji, który zakłada poczucie dumy oraz radości z wykonywanej pracy, a także wewnętrzną potrzebę dążenia do doskonałości zawodowej,

- świadome uznanie obowiązku społecznego - rozumiane jako przestrzeganie ideałów i norm profesji, zdobywanie dla niej publicznego zrozumienia i uznania oraz np. świadczenie darmowych usług publicznych jako swoista zapłata społeczeństwu za przywilej wykształcenia i zdobycia statusu zawodowego (Grudziewska, Lewicka-Zelent 2015: 43). 
Historycznie kodeksy etyczne czy zawodowe powstawały już w czasach antycznych w związku z pragmatyką wojskową, ale formalizowanie zasad postępowania, zanim skodyfikował je legislator, przyjmowały środowiska o wyeksponowanym znaczeniu w praktyce społecznej, np. gildie kupieckie. Na gruncie polskim jeszcze w latach 80 . XX wieku kodeksy należały do rzadkości i dotyczyły tylko profesji uważanych obecnie za zawody zaufania publicznego. Zdecydowane ożywienie $\mathrm{w}$ tworzeniu zbiorów zasad poza samorządami zawodów zaufania publicznego nastąpiło w okresie zmian ustrojowych i gospodarczych, tj. po 1990 roku.

Oceny i normy moralne kształtują się w danym środowisku społecznym czasem w sposób spontaniczny, w związku z brakiem uregulowań prawnych w danej dziedzinie, jak w przypadku kodeksu mediatora, ale i wypracowane jako zasób doświadczeń, mogą zostać ułożone w zbiór w postaci określonej doktryny moralnej (Zacharzewski 2011: 35-36). Środowiska zawodowe przy tworzeniu kodeksów deontologicznych odnoszą się do podstaw wartości fundamentalnych, czego efektem jest tak ukształtowana relacja społeczna, by wypełniała moralną zasadę praworządności. Stanowi ona, że działanie człowieka jest etyczne wtedy, gdy jest zgodne z wolą człowieka i prawem powszechnym, z którym identyfikuje się każdy. Dawanie każdemu, co byśmy chcieli, aby się należało, powinno być dawaniem uczciwym i powszechnie aprobowanym (Zacharzewski 2011: 103). Tworzenie kodeksów następuje w oparciu o moralną zasadę sprawiedliwości, która orzeka, że działanie jest etyczne, jeśli zachowuje równość, proporcjonalność lub wzajemność, a powoduje dawanie każdemu, co się mu należy (Zacharzewski 2011: 89).

Helping professions traktujemy w tej pracy jako profesje, których zadaniem jest rozwijanie, rozwiązywanie problemów związanych z dobrostanem psychicznym, emocjonalnym, fizycznym, duchowym czy też intelektualnym, związanych $\mathrm{z}$ pracą socjalną, mediacją rozumianą jako pomoc w rozwiązywaniu problemów, medycyną, psychoterapią, poradnictwem psychologicznym, edukacją i szkoleniem. Osoby wykonujące te profesje określane będą w tym artykule również jako helper, helpoworker.

Helping professions to materia wyjątkowa i delikatna ze względu na swój charakter, to zawody, które są zawodami zaufania publicznego, co dodatkowo kładzie nacisk na ważność potrzeb i interesów drugiego człowieka - klienta, beneficjenta, ucznia, pacjenta. Podmiot, który jest słabszy, wrażliwszy ze względu na swoje potrzeby i trudną sytuację, winien zostać objęty profesjonalną opieką i pomocą. Przykładem funkcjonowania etyki zawodowej w praktyce może być dylemat dotyczący tego, jak postępować w sytuacji konfliktu norm. W związku z ułomnością ludzkiej natury dochodzi również do sprzeczności między normami (abstrakcyjna sprzeczność norm) (Łabieniec 2002: 30). Następuje to w sytuacji, gdy mają one choćby częściowo wspólny zakres zastosowania, a przy tym jedna $\mathrm{z}$ tych norm nakazuje lub dozwala i odwrotnie $-\mathrm{z}$ tego powodu nie jest możliwe łączne spełnienie obu norm przez żadnego lub jednego adresata, gdyż spełnienie 
jednej z nich czyni niemożliwym spełnienie drugiej. W związku z wysoką profesjonalizacją zawodu pracownika socjalnego nałożono na niego również obowiązek stosowania mediacji w sytuacji sporów. Porównując zatem kodeks mediatora z Ustawą o pomocy społecznej, która reguluje sprawy związane z zawodem pracownika społecznego, widzimy wyraźnie, że spełnienie kardynalnej zasady, jaka charakteryzuje proces mediacji, tj. zasady poufności, wyklucza się z działaniem pracownika socjalnego w sytuacji, w której otrzymał on informację o popełnieniu przestępstwa. Nie może dochować tej zasady, gdyż jako urzędnik zobowiązany jest do każdorazowego zgłoszenia takiej sytuacji. Teorie prawa naturalnego stoją na stanowisku, że norma prawna sprzeczna $\mathrm{z}$ wymogami prawa naturalnego, które jest jednocześnie prawem moralnym - a w takim ujęciu to porównanie nas interesuje - nie obowiązuje, choćby spełniała wszystkie formalne wymagania dotyczące stanowienia prawa. Czy więc taki pracownik socjalny powinien wykazać się moralnością zgodną z kodeksem etyki (choćby mediatora, przy używaniu mediacji $\mathrm{w}$ swojej pracy) czy powinnością urzędową wynikającą z przepisów prawa? Czy normy wynikające z kodeksu etycznego należy potraktować jako normy hierarchicznie niższe i jako takie byłyby one derogowane przez normy prawne?

\section{Analiza wybranych kodeksów etycznych zawodów pomocowych w kontekście poszukiwania wspólnej deontologii profesjonalnego pomagania}

O ile celem refleksji deontologicznych jest formułowanie zasad powinnościowego zachowania, o tyle poniższa refleksja dotyczyć będzie cech wspólnych, wspólnych powinności kodeksów zawodowych helping professions, gdyż stanowią one dość jednorodną kategorię.

W podjętych analizach $\mathrm{w}$ kontekście poszukiwania wspólnej deontologii profesjonalnego pomagania uwaga koncentrować się będzie na wybranych kodeksach etycznych, tj. Kodeksie Etyki Mediatorów Polskich i Kodeksie Etycznym Polskiego Towarzystwa Pracowników Socjalnych. Pod wieloma względami sytuacja tego pierwszego jest nietuzinkowa, natomiast wyjątkowość, a zarazem trudność zawodu pracownika socjalnego polega na uniwersalności cech profesji w połączeniu z wymogiem wysokich kwalifikacji, posiadania kompetencji i wiedzy charakterystycznych dla innych zawodów oraz największym ze wszystkich helping professions zinstytucjonalizowaniem. Porównano je dodatkowo z zawodem lekarza (Kodeks Etyki Lekarskiej, uchwalony przez Nadzwyczajny VII Krajowy Zjazd Lekarzy w 2003 roku $^{3}$ ), psychologa (Kodeks Etyczno-Zawodowy

${ }^{3}$ http://www.nil.org.pl/_data/assets/pdf_file/0003/4764/Kodeks-Etyki-Lekarskiej.pdf [dostęp 25.06.2017]. 
Psychologa z 1992 roku $^{4}$ ), psychoterapeuty (Kodeks Etyki Zawodowej Psychoterapeuty Polskiej Federacji Psychoterapii z 2005 roku$^{5}$ ), terapeuty uzależnień (Kodeks Etyczny Terapeuty Uzależnień z 2007 roku), nauczyciela (Kodeks Etyki Nauczyciela z 1995 roku), kuratora (Kodeks Etyki Kuratora Sądowego z 2004 roku).

Rozpoczynając analizę Kodeksu Etyki Mediatorów Polskich, należałoby się przyjrzeć organowi, który go utworzył. Społeczna Rada ds. Alternatywnych Metod Rozwiązywania Konfliktów i Sporów przy Ministrze Sprawiedliwości powstała Zarządzeniem Ministra Sprawiedliwości (Zarządzenie Ministra Sprawiedliwości nr 55/08/DNWO z dnia 1.08.2005 r.) na podstawie art. 7 ust. 4 pkt 5 ustawy z dnia 8 sierpnia 1996 r. o Radzie Ministrów. Minister w zarządzeniu określa, że jest ona ciałem doradczym Ministra Sprawiedliwości. § 2 tego zarządzenia określa jednoznacznie, że oprócz przedstawicieli organizacji pozarządowych i instytucji naukowych w skład Rady będą wchodzić również przedstawiciele resortów - czterech ministerstw. § 3 zaś określa obowiązki Rady, w tym m.in. opracowanie kodeksu etyki. Czy jednak w obliczu braku ustawy o ADR - w tym o mediacji - Rada ma wystarczające uprawnienia? Należałoby się zastanowić nad legitymacją prawną, a nawet etyczną, by odpowiedzieć na pytanie, czy taki organ był uprawniony do stworzenia kodeksu etyki. Trybunał Konstytucyjny (Postanowienie Trybunału Konstytucyjnego z dnia 7.10.1992 r. U 1/92) w swoim postanowieniu, podając przykład kodeksu etyki lekarskiej, zauważył, że normy zawarte w kodeksie mają charakter norm deontologicznych, a nie należących do zakresu administracji państwowej. Stanowienie norm deontologicznych nie należy do organu państwa, zatem państwo nie jest upoważnione do zlecenia ustanowienia tych norm komukolwiek, bowiem państwo tworzy normy prawne. Idąc dalej, żaden organ administracji państwowej nie był i nie może być uprawniony do określania norm deontologicznych. Czy należy zatem przyjąć, że choć kodeks nie ma wiążącej mocy prawnej, to etycznie obowiązuje tych, do których jest adresowany?

Jak wspomniano wcześniej, zawód mediatora nie ma swoich jednolitych unormowań prawnych, nie ma również obiecywanej od wielu lat ustawy o ADR (alternative dispute resolution - alternatywne pozasądowe sposoby rozwiązywania sporów i konfliktów). Dlatego też ważne w analizowaniu zasad moralnych, etycznych, ale i zwykłych powinności czy obowiązków są Kodeks Etyki Mediatorów Polskich ${ }^{6}$ i Standardy Prowadzenia Mediacji i Postępowania Mediatora. Nietuzinkowość Kodeksu Etyki Mediatorów Polskich polega chociażby na tym, że Społeczna Rada ADR, złożona z przedstawicieli resortów wraz z członkami organizacji i stowarzyszeń mediatorów, zamiast stworzyć od razu działające przepisy prawa, w pierwszej kolejności (w 2006 roku) stworzyła standardy prowadzenia mediacji, a dwa lata później kodeks etyczny - mamy zatem dwa źródła

\footnotetext{
${ }^{4} \mathrm{http}: / /$ www.ptp.org.pl/modules.php?name=News\&file=article\&sid=29 [dostęp 25.06.2017].

${ }^{5}$ http://www.psychoterapia-polska.org/kodeks-etyczny-pfp [dostęp 25.06.2017].

${ }^{6}$ https://ms.gov.pl/Data/Files/_public/mediacje/adr1/kodeksetyczny.pdf [dostęp 25.06.2017].
} 
deontologiczne, które zamiast się uzupełniać, pokrywają się. Poza tym można wskazać kilka innych cech charakterystycznych dla zawodu mediatora stanowiących o specyfice tej profesji:

1) Mediator wśród innych zawodów pomocowych ma o tyle utrudnione działanie, że jego klientem nie jest pacjent, chory czy inny potrzebujący, ale dwa zawsze przeciwstawne względem siebie stanowiska (przedmiotem jest spór pomiędzy dwiema stronami), dwie zwalczające się wzajemnie „frakcje”. Mediator nie dość, że musi być bezstronny i neutralny wobec nich, z naciskiem na kierowanie się dobrem klienta (ciekawe, co ustawodawca miał na myśli, pisząc o stronie/ kliencie w liczbie pojedynczej), a także wobec problemu sporu, to jeszcze powinien stworzyć takie warunki, by strony miały sposobność do znalezienia rozwiązania i poczucie, że nie zostało ono im narzucone przez mediatora.

2) Zawód mediatora jest relatywnie nowy, umiejętności niezbędne w tym zawodzie wykorzystywane były i nadal są również w innych zawodach: pracownika socjalnego, animatora, psychologa-terapeuty, kuratora, policjanta itd. Rola mediatora jest jedną z ważniejszych i najczęściej wymienianych wśród ról zawodowych pracownika socjalnego (por. Olech 2012: 337).

3) Wraz z wyodrębnieniem i specjalizacją roli mediatora pojawiła się profesjonalizacja i instytucjonalizacja umiejętności mediacyjnych, a co za tym idzie zawodu mediatora. Nie oznacza to, że umiejętności te przestały być potrzebne w innych zawodach pomocowych, a jedynie to, że przedstawiciele owych zawodów mogą liczyć na wsparcie niezależnego profesjonalisty.

4) Ponadto, profesjonalny mediator również jest zawodem, który - na wzór pracownika socjalnego - można uznać za multidyscyplinarny.

Praca socjalna to dziedzina, której celem jest pomaganie jednostkom, grupom i społecznościom w odzyskiwaniu zdolności do samodzielnego funkcjonowania na akceptowalnym $w$ danym społeczeństwie poziomie. Pracownik socjalny napotyka w swojej pracy wiele problemów, które dotyczą nie tylko sfery materialnej społecznego funkcjonowania klientów, ale również, a może przede wszystkim, kwestii ludzkiej godności. Bierność, ubóstwo, bezrobocie, uzależnienia, samotność, choroby, krzywda to problemy, z którymi zmagają się odbiorcy pomocy służb społecznych. Dlatego wobec pracy socjalnej stawia się wyjątkowo duże wymogi i oczekiwania; jest ona profesją, która szybko stała się zawodem zaufania publicznego. Skodyfikowanie wymogów i standardów pracy socjalnej było bodaj najważniejszym krokiem do profesjonalizacji i instytucjonalizacji zawodu pracownika socjalnego. Zasady i cele pracy socjalnej, a także prawa i obowiązki pracownika socjalnego zostały zawarte m.in. w Ustawie o pomocy społecznej, Kodeksie Etycznym Polskiego Towarzystwa Pracowników Socjalnych, a także w wielu ważnych podręcznikach (z najnowszych można wskazać m.in. Dylematy etyczne pracowników socjalnych pod red. Marty Sokołowskiej z 2013 roku).

Praca socjalna to szczególna dziedzina w obszarze profesjonalnego pomagania. Możemy mówić o kilku cechach stanowiących o istocie pracy socjalnej, m.in.: 
1. Praca socjalna to zarówno dziedzina nauki, jak i praktyczna działalność pomocowa. Jest zatem dziedziną umocowaną na bogatych fundamentach naukowych, ale jej cele są bardziej dalekosiężne, bowiem pragmatyczne, praktyczne, nakierowane na pracę $\mathrm{z}$ klientem i na jego rzecz.

2. Praca socjalna, podobnie jak psychologia, to interdyscyplinarna aktywność zawodowa zlokalizowana w kilku obszarach usług społecznych: pomocy społecznej, wymiarze sprawiedliwości, edukacji czy ochronie zdrowia (Olech 2012: 333), i będąca w kręgu zainteresowania różnych dyscyplin naukowych. Czerpie ona bowiem zarówno z nauk społecznych, jak i z prawa, psychologii, pedagogiki, ekonomii, jest wykorzystywana w sferze administracji, wymiaru sprawiedliwości, edukacji, pomocy społecznej, terapii, a nawet gospodarki.

3. Praca socjalna to zarówno działalność polityczna, jak i bezpośrednia praktyka społeczna, czyli praca z konkretnymi osobami, rodzinami, grupami. Praktyczna praca socjalna, czyli kliniczna praca socjalna, dokonuje zmian na poziomie mikro, zapewnia klientom dostęp do środków i zasobów społeczeństwa, zaś praca socjalna w wymiarze politycznym (bliższa polityki społecznej) stoi na straży praw socjalnych dzięki temu, że otwiera możliwości udostępniania środków i tworzenia korzystnych warunków do rozwoju. Oba te wymiary - praktyczny i polityczny - wpływają na siebie nawzajem i wzajemnie się przenikają, dlatego oba powinny być uwzględniane w pracy pracowników socjalnych (Kudlińska, Kacprzak 2011: 100)

4. Praca socjalna to dziedzina, która szczególnie powinna odwoływać się do wartości społecznych. Dokonywanie ciągłych wyborów w codziennej pracy wymusza odwoływanie się i aplikowanie określonych zasad etycznych, a do najważniejszych w pracy socjalnej zalicza się: uznanie godności osoby ludzkiej, szacunek, sprawiedliwość społeczną, równość i solidarność społeczną. Co więcej, $\mathrm{w}$ istotę pracy socjalnej wpisane są dylematy etyczne i konflikt norm, zwłaszcza że pracownik socjalny pełni kilka ról zawodowych, z których dwie mogą czasem pozostawać w konflikcie - występuje on zarazem jako reprezentant władzy (biurokratycznej instytucji państwowej), a jednocześnie bliski bezsilnemu klientowi kliniczny pracownik socjalny.

Etyka pracy socjalnej, która determinuje wybory w praktyce, kształtuje zarówno sposoby myślenia, jak i sposoby działania - te w wymiarze klinicznym, jak i politycznym. Wszystkie te elementy powinny być rozważane w szerszym kontekście aksjologicznych podstaw pracy socjalnej. Przykładem koncepcji spełniającej ten wymóg może być koncepcja autorstwa Karli Miley i Brendy DuBois 16 wartości etycznych, pogrupowanych według wymiarów praktycznego i politycznego pracy socjalnej oraz kształtowanych sposobów myślenia i sposobów działania. Do zasad kształtujących sposoby myślenia praktycznej (klinicznej) pracy socjalnej autorki zaliczają: etykę opieki, autonomii, możliwości i zmiany. Do zasad kształtujących sposoby działania praktycznej (klinicznej) pracy socjalnej autorki zaliczają: etykę szacunku, krytycznego myślenia, etykę praxis i etykę 
dyskursu. Do zasad kształtujących sposoby myślenia politycznej pracy socjalnej autorki zaliczają: etykę krytyki, sprawiedliwości, kontekstualnej praktyki oraz inkluzji. Do zasad kształtujących sposoby działania politycznej pracy socjalnej autorki zaliczają: etykę antyopresji, obrony, współpracy i upolitycznionej praktyki (Miley, DuBois 2007, za: Kudlińska, Kacprzak 2011: 101-104). Realizacja tych zasad w praktyce stanowi istotę współczesnej profesjonalnej pracy socjalnej, której celem będzie upełnomocnienie klienta, czyli wyposażenie go w odpowiednie zasoby i zdolności, a także umożliwienie mu dostępu do społecznych zasobów i społecznego wsparcia.

Do analizy kodeksów etycznych przyjęto:

1. Sposób powołania do życia kodeksów etycznych. Tylko w przypadku Kodeksu Etyki Mediatorów Polskich powołania nie dokonała organizacja zrzeszająca specjalistów z tej dziedziny, ale organ państwowy.

2. Analizę zawartości treści wymienionych dokumentów. Poszukiwano najczęściej pożądanych i oczekiwanych cech oraz działań. W związku z faktem, iż wiele ze zmiennych określano inaczej w różnych dokumentach, wybrano następujące:

- obowiązek doskonalenia zawodowego - ta grupa obowiązków określana była jako: rozwój zawodowy, podnoszenie kwalifikacji zawodowych i doskonalenie zawodowe - wymieniona była w ośmiu na dziewięć analizowanych kodeksów;

- poufność - zawiera katalog różnorodnych określeń: prawo do intymności, prywatność, poufność, tajemnica zawodowa, dyskrecja - występowała w ośmiu dokumentach na dziewięć;

- równe traktowanie - określano inaczej jako: niedyskryminowanie, prawa człowieka, prawo do równego traktowania, prawo do samostanowienia, prawo do podejmowania decyzji, bezstronność w stosunku do stron (dot. mediatora jako jedynej profesji, która podejmuje działania w kontekście dwóch osób/stron) - istotna dla ośmiu z dziewięciu aktów;

- rzetelność - grupa różnorodnie określana, występująca właściwie we wszystkich kodeksach, rozumiana jako: stosunek do kolegów ze środowiska, kolegów „po fachu”, troska o prestiż środowiska rozumianego jako branża, wspieranie własnego środowiska, ale i rzetelne przedstawianie własnych kompetencji, uczciwe informowanie o stanowiskach, stopniach naukowych, uczestnictwo w stowarzyszeniach zawodowych, informowanie o kwestiach wynagrodzenia $i$ innych czynnikach dotyczących pracy i osoby helpworkera;

- godność - rozumiana jako prawo do samostanowienia, prawo do podejmowania decyzji, ale również mówienia „nie”, zgoda beneficjenta na udział w działaniach pomocowych.

Konstrukcja współczesnych kodeksów etycznych jest dość jednolita. Każdy z nich zaczyna się od preambuły lub też wstępu, a po nim następuje część właściwa, czyli zasady, podzielona czasem (ze względu na liczbę paragrafów) na część 
ogólną i szczególną lub na części regulujące stosunek danego zawodu do innych, np. stosunek do pacjenta, stosunek do własnego środowiska. Kodeks mediatorów jest najbardziej ubogi w formie i treści ze wszystkich analizowanych kodeksów aktem. Zawiera jedynie XII zasad, w porównaniu do 76 paragrafów kodeksu lekarskiego, 36 punktów kodeksu pracownika socjalnego, 51 punktów, które zawiera kodeks psychologa, 67 punktów kodeksu psychoterapeuty, 25 punktów terapeuty, 56 punktów kodeksu nauczyciela, 16 artykułów kodeksu kuratora sądowego i 13 zapisów wolontariusza.

Po dokładnej analizie kodeksów etycznych służb nastawionych na pomoc człowiekowi i rodzinie, można wyróżnić wspólną ich aksjologię, która skupiona jest wokół jednego obszaru poszanowania człowieka, jego prawa do samostanowienia, godności.

Na pierwszy plan - ze względu na liczbę kodeksów, które o tym mówią, i miejsce, jakie temu poświęcają - wysuwa się stawianie helpersom obowiązku doskonalenia zawodowego, określanego jako rozwój zawodowy, doskonalenie wiedzy, pogłębianie wiedzy, podnoszenie kwalifikacji. Odpowiedzialne podejście do pomagania ludziom oraz świadomość zadań, jakie są związane z daną rolą zawodową, nakładają na każdego z nich obowiązek ciągłego podnoszenia kwalifikacji, odbywania szkoleń, śledzenia literatury z danego zakresu, monitorowania na bieżąco zmian w regulacjach prawnych danego zawodu, tak by wykonywana praca była nie tylko skuteczna i wartościowa, ale i zgodna z przepisami (Huflejt-Łukasik 2010: 199-210). To tomizm i arystotelesowski perfekcjonizm traktują jako doskonałość moralną, wartość sprawności, która kształtuje charakter. U obu akcent pada na empirię, doświadczenie, ćwiczenie się, trening - powiązane nieodłącznie $\mathrm{z}$ pogłębianiem wiedzy $\mathrm{w}$ formie nauki, ale i treningu umiejętności. Kiedyś wzorcem helpera była osoba z wielkim sercem, pasją i charyzmą, często po własnych trudnych przejściach, a dziś to przede wszystkim osoba wysoko sprofesjonalizowana i ciągle doszkalająca się.

$\mathrm{Na}$ równi wybrzmiewa prawo do poufności, przestrzegania tajemnicy zawodowej, związanej z tym intymności, prywatności i dyskrecji. To niezwykle ważna zasada, gdyż dzięki niej budowana jest relacja między pomagającym a wspomaganym, relacja, która powinna opierać się na zaufaniu, bezpieczeństwie stron, głównie tej słabszej. Ta wartość związana jest głównie z etyką personalistów, gdzie w centrum stawiany jest człowiek z jego godnością i prawami, ale i filozofią dialogu i spotkania, rozwijaną w Polsce przez dociekania J. Tischnera, w których chodzi głównie o prawdę.

W tym samym nurcie (filozofii dialogu, spotkania), a ściśle związana z prawem do tajemnicy, poufności i dyskrecji, jest akceptacja inności, czyli prawo do równego traktowania, obowiązek niedyskryminowania, szacunku - opisane w większości kodeksów, a związane z prawami człowieka bez względu na kolor jego skóry, rasę, wyznanie, pochodzenie i inne, drażliwe społecznie okoliczności z osobą ludzką związane. Istnieje obowiązek oddzielenia własnej osoby, 
przekonań, sposobu myślenia, światopoglądu i wartości od tego, z czym osoba pomagająca ma do czynienia na co dzień, czego akceptować nie musi, ale szanować już powinna. Tej wartości głębiej wyjaśniać i racjonalizować nie ma potrzeby, jest ona oczywista, gdyż wpisuje się w podstawowe prawa człowieka i ściśle związana (znów) jest z godnością człowieka. Oczywiście różne kodeksy w różny sposób traktują prawo do tajemnicy, poufności. Regulacje pokazują sytuacje, w których ta powinność może być naruszona, kiedy dla realizacji innej powinności należy tę etykę zawiesić. Należy tu przywołać Schelerowskie podejście hierarchizowania wartości, np. pracownik socjalny może naruszyć poufność w sytuacji, kiedy otrzyma informację o popełnionym przestępstwie. Inny helpworker powinien naruszyć tę zasadę, gdyby w grę wchodziła ochrona zdrowia lub życia drugiego człowieka. Właściwie wolny od konieczności naruszania tej wartości jest tylko mediator, który w pełni może wcielać tę etykę w swojej pracy.

Wartość, jaką jest godność, wpisuje się całkowicie w kolejną łączącą wszystkich helpersów powinność, a mianowicie w prawo do samostanowienia, prawo do podejmowania decyzji, ale również do mówienia „nie” (klient w procesie mediacji zawsze ma prawo powiedzieć „nie” zarówno mediatorowi, jak i samemu procesowi mediacji, w terapii, w leczeniu). Godność i poszanowanie człowieka, jako całości, jako niezależnego bytu, obdarzonego wolnością, świadomością i wolą, to prawo niezbywalne, akcentowane przez wszystkie etyki personalistyczne (nowożytną etykę Kanta, starożytno-scholastyczną klasyczną, XX-wieczną chrześcijańską, etykę Schelera).

Kolejną wartością wspólną dla wielu kodeksów jest obowiązkowość, ściśle związana $\mathrm{z}$ uczciwością, a wyrażana $\mathrm{w}$ takich zasadach, jak: rzetelne przedstawianie własnych kompetencji, uczciwe informowanie o stanowiskach, stopniach naukowych, uczestnictwo w stowarzyszeniach zawodowych, informowanie o kwestiach wynagrodzenia i innych czynnikach dotyczących pracy i osoby helpworkera. To co etyczne, a wpisujące się w obowiązkowość i uczciwość, to również niepobieranie korzyści materialnych z faktu kierowania klienta/pacjenta do innego specjalisty. W ocenie autorki tekstu, do powinności dotyczących niebezpośrednio stosunku do wspomaganego należy również odpowiednie odnoszenie się do „kolegów po fachu”, z którymi połączyć możemy troskę o prestiż środowiska i wspieranie tego środowiska w działaniach. Odpowiedni stosunek polega na nieoskarżaniu, wyjaśnianiu sytuacji konfliktowych, lojalności wobec innych członków stowarzyszeń.

Ostatnią wspólną wartością dla pomagających, a związaną z odpowiedzialnością, jest oddzielenie strefy prywatnej od zawodowej, wyrażające się poprzez zakaz wchodzenia w relacje bliskości fizycznej i emocjonalnej, np. zakaz wiązania się z pacjentami, uczniami, klientami. To oczywiście wpisuje się w poprzednie wartości: poszanowania godności, uczciwości, równego traktowania. Zasada bezstronności z etyki mediatora, mówiąca o braku jakiejkolwiek zależności ze stroną sporu, wypełnia tę etykę. Odpowiedzialność jest szerokim i trudnym 
do zdefiniowania pojęciem. Istotę odpowiedzialności w kontekście deontologii pomagania doskonale oddaje odpowiedź Józefa Tischnera na pytanie, dlaczego Ingarden uczynił odpowiedzialność „kluczem do wnętrza bytu ludzkiego”. Otóż:

Człowiek to istota skierowana ku wartościom. Jeśli tak, to trzeba powiedzieć, że właśnie w poczuciu odpowiedzialności wyraża się w sposób najbardziej źródłowy prawda o człowieku. To ono wyróżnia i wiąże człowieka ze światem, ono świadczy o jego wolności i skierowaniu ku wartościom i w nim wyraża się najpełniej to szczególne zaufanie człowieka do własnego istnienia, które nie pozwala mu tracić swego czasu (Tischner 1981, za: Łuczyńska 2010: 104).

Reasumując dotychczasowe rozważania na temat deontologii wspólnej służb skoncentrowanych na pomaganiu, nie można pominąć, jak już wspomniano w poprzednim rozdziale, osadzenia jej w konkretnym systemie filozoficzno-etycznym. Szukając podstaw dla uzasadnienia zachowań helpworkers w systemach filozoficznych, nie sposób nie uznać zasług Kanta z jego etyką obowiązku, w której człowiek jest tym bardziej moralny, im bardziej musi się przełamywać, przezwyciężać siebie, im trudniej przychodzi mu czynić dobro, im więcej wysiłku kosztuje go to etyczne postępowanie (słuchanie wewnętrznego prawa moralnego), a więc owo czynienie dobra. Idąc tym tokiem myślenia, należałoby uznać, iż bardziej moralny jest ten pracownik służb społecznych, który udziela pomocy (z zachowaniem norm etycznych) z obowiązku zawodowego niż ten działający spontanicznie (Kaczyńska 2010). Bo czyż nie trudniej jest spełniać obowiązki w tak trudnej etycznie i moralnie materii, jaką jest pomaganie innym, jeśli kosztuje nas więcej wysiłku czynienie takiego dobra. Według Wandy Kaczyńskiej (2010), najlepsze jednak jest podejście w rozumieniu etyki arystotelesowsko-tomistycznej, która przykłada ogromną wagę do ćwiczenia praktycznych umiejętności etycznego postępowania. Etyczność według tej teorii polega na sprawności w czynieniu dobra, w postępowaniu etycznym, a etyczny jest ten, kto z łatwością, niejako z przyzwyczajenia, czyni dobro, kto jest tak w tym wprawiony, że wręcz nie umie postępować źle. Światowej sławy filozof Józef Bocheński podkreśla, że w sprawnym działaniu etycznym nie wystarczy „nabycie teoretycznych wiadomości, a więc nauka”, lecz także „chodzi o działanie praktyczne” (Bocheński 2015, za: Kaczyńska 2010: 291). Etyczny jest ten, kto nie tylko wie, ale i potrafi. W ocenie autorki prezentowanego tutaj tekstu (jako praktyka mediatora), jeśli mówimy i analizujemy profesjonalizację helping proffesions, nie jest w ogóle możliwe rozłączenie ,wiem” od „potrafię”, gdyż profesjonalistą staje się ten, kto umie zastosować zdobytą wiedzę w praktyce.

W literaturze przedmiotu można znaleźć pogląd, iż idealne byłoby podejście personalistyczne głoszone przez Karola Wojtyłę, a zakładające personalne podejście do człowieka jako fundament wszelkich działań na rzecz potrzebującego, bezradnego, chorego, wykluczonego, z jakiegoś powodu słabszego w swojej sytuacji. Należy postępować tak, by człowieka, tak w swojej osobie, jak i w osobie każdego innego, używać zawsze jako celu, nigdy jako środka - mówił Kant, 
a polscy personaliści głoszą powinność afirmowania czynem osoby ze względu na nią samą, na jej wyjątkową godność i wartość. Personalistyczna etyka łączy w sobie zarówno Kantowską etykę obowiązku z arystotelesowsko-tomistycznym umiłowaniem praktyki jako wartości i Schelerowskim ${ }^{8}$ uhierarchizowaniem tych wartości, z zaleceniem, by w przypadku konfliktu pomiędzy tymi wartościami zrealizować tę, która stoi wyżej, kosztem tej stojącej niżej. Dla zrozumienia osadzenia etyk osób zawodowo zajmujących się pomaganiem wydawać się może, że jedna bez pozostałych nie może funkcjonować, a pominięcie którejś z nich wydaje się czynić rozważanie i analizowanie niepełnym. Bo czyż można samodzielnie Kantowską etykę obowiązku traktować jako matrycę etyczną dla wspomagających, kiedy mówi ona o samym obowiązku, a nie wskazuje, jakie wartości stosować i które z nich są ważne, a które ważniejsze? Z kolei, czy etyka Maxa Schelera wystarczyłaby jako regulator działalności służb społecznych, skoro analiza kodeksów pokazuje, że składają się one również z zakazów i nakazów, chociaż głównie powinny być wskazówkami do tego, jak postępować, a nie wykładnią (poza oczywiście zapisami, które mogą wprowadzać nowy ład organizacyjny i prawny), choć traktują również o wartościach, które są podstawą owych zakazów i nakazów (Kaczyńska 2010: 305-306).

\section{Zakończenie}

Rozwój zawodów pomocowych zdecydowanie idzie w kierunku rozszerzania kompetencji, podnoszenia kwalifikacji w sposób poziomy, czyli nie poprzez pogłębianie głównych kompetencji danego zawodu, ale dokładanie kolejnych umiejętności charakterystycznych dla innych zawodów, o które wzrasta profesjonalizacja. Ma to niewątpliwe - choć bywa, że pozorne - zalety. Beneficjent czy też klient - odbiorca usługi czy też działań zawodowych w ,jednym miejscu i jednym czasie” otrzymuje kompletną informację na temat swojego problemu. Oczywiście, martwić się należy o to, i w tym kierunku powinny iść badania i dyskurs, czy przekazana treść jest w pełni zgodna ze stanem faktycznym i prawnym? Czy używanie tych dodatkowych kompetencji, charakterystycznych dla innych zawodów, niesie ze sobą bezpieczeństwo dla ich odbiorcy? Rację/wyższość ma ten, kto używa ich tylko do zdiagnozowania sytuacji, a potem do skierowania danej osoby do właściwego specjalisty, a mocno (w świetle doświadczenia zawodowego mediatora-autorki artykułu) ryzykuje ten, kto wciela się w role jemu dodane. Przykładem może być konflikt ról mediatora i pracownika socjalnego. Krzywdę jedynie może zrobić mediator niebędący prawnikiem, a tylko przeszkolony z przepisów prawa i sporządzający ugodę zmieniającą stan prawny i wprowadzającą nowy ład. Podobnie wygląda sytuacja

\footnotetext{
${ }^{7}$ Karol Wojtyła, Tadeusz Styczeń oraz Andrzej Szostek.

${ }^{8}$ Max Scheler.
} 
w przypadku pracownika socjalnego, który stara się wcielić w rolę mediatora, będąc jednocześnie przedstawicielem urzędu.

Mając na względzie kierunki rozwoju zawodów pomocowych, uważa się, iż najważniejszą ze wspólnych deontologii powinna być troska o dobro klienta/ pacjenta. Tak szeroka profesjonalizacja zawodów i nakładanie na helpersów coraz to nowych wymogów („,musisz wiedzieć”/,musisz umieć”), charakterystycznych dla innych zawodów, może doprowadzić do tego, że priorytetem przestanie być klient/pacjent, a najważniejsze stanie się wykorzystywanie i wdrażanie wszystkiego, czego nauczono i co narzucono do stosowania pracownikowi pomocowemu. Rozwiązaniem tego problemu powinna być częstsza akumulacja doświadczeń praktycznych ${ }^{9}$ osób reprezentujących inne zawody pomocowe, w której to na rzecz jednej osoby/rodziny czy też grupy osób pracuje kilku profesjonalistów reprezentujących zawody pomocowe, włączających się w szeroko rozumianą pracę socjalną, ale niebędących etatowymi pracownikami socjalnymi, np. terapeuci, mediatorzy, lekarze, a nawet prawnicy. Wpisuje się to również w nurt ekspansywny (Rymsza 2014) profesjonalizacji pracy socjalnej, związany z wyłanianiem nowych specjalności i zawodów pomocowych z już istniejących. Doskonałym przykładem są tu streetworkerzy, animatorzy i organizatorzy społeczności lokalnej, których pojawienie się było odpowiedzią na potrzeby pracy socjalnej i zbyt duże obciążenie obowiązkami pracowników socjalnych.

W literaturze przedmiotu powstał pogląd, że refleksja socjologiczna nad procesem profesjonalizacji służb społecznych w Polsce jest relatywnie niewielka, co może doprowadzić m.in. do sporów kompetencyjnych między różnymi zawodami i specjalnościami pomocowymi, chociażby w sytuacji niezbędnej współpracy, o której wspomniano uprzednio, jak również z tymi nowo powstającymi. Wskazana refleksja ma służyć głównie katalizowaniu procesów rozwojowych we współpracy środowisk helperskich, bez oczekiwania na ustawowe rozwiązania narzucone odgórnie. Analiza socjologiczna pozwoli dostrzec tworzenie się nowych specjalności w obrębie pracy socjalnej i ich wybijanie się „na niepodległość" bez szkody dla samej pracy socjalnej. Ta idea ma uwrażliwić na tworzenie się wspólnej reprezentacji środowiskowej i funkcjonalnej współpracy przedstawicieli różnych zawodów pomocowych, przekraczającej partykularne interesy grupowe. W literaturze znany jest również pogląd odmienny (np. Granosik 2014: 50), ujawniający, że zespoły interdyscyplinarne nie potwierdzały pozytywnych doświadczeń przynoszących korzystne rozwiązania trudnych sytuacji, gdyż sprowadzały rolę pracownika socjalnego do roli asystenta. Być może przyczyna niepowodzenia leżała w odgórnym powoływaniu tych tworów z narzuconą im rolą. Jest to niewątpliwie kolejny dowód na to, że brak szerszej refleksji i dogłębnej analizy powodować może antagonizmy wśród środowisk pomocowych. Inicjatywa, jak

${ }^{9}$ Nurt praktyczny jest jednym z czterech nurtów profesjonalizacji pracy socjalnej, które zaobserwowano po 1989 r. Pozostałe nurty to instytucjonalny, edukacyjny, ekspansyjny. 
wspomniano wcześniej, winna wyjść od przedstawicieli poszczególnych zawodów pomocowych ${ }^{10}$, a wola działania opierać się na chęciach i pozytywnym nastawieniu. Niezbędna jest nie tylko mentalna zmiana poszczególnych osób, ale przede wszystkim zmiana filozoficznych fundamentów w myśleniu grup zawodowych.

Prezentowany artykuł wpisuje się w niezwykle ważną i aktualną interdyscyplinarną dyskusję o pomaganiu, deontologii, nie tylko o tym, jak i komu, ale w jaki sposób pomagać. Rozważania i analiza dotyczą tego, jakie wspólne cechy czy też podstawy aksjologiczne, a w konsekwencji obowiązki etyczno-moralne, łączą helpersów.

\section{Bibliografia}

Blackburn S. (1997), Oksfordzki słownik filozoficzny, thum. C. Cieśliński, P. Dziliński, M. Szczubiałka, J. Woleński, hasło: Deontologia, oprac. J. Woleński, Książka i Wiedza, Warszawa.

Bocheński J. (1995), Dzieła zebrane, t. V: Etyka, Wydawnictwo Philed, Kraków.

Granosik M. (2016), Od profesjonalnej nadziei do procedur. Dyskursywna instytucjonalizacja polskiej pracy socjalnej, „Problemy Polityki Społecznej. Studia i Dyskusje”, nr 35(4), s. 43-58, www.problemypolitykispolecznej.pl [dostęp 10.09.2017].

Grudziewska E., Lewicka-Zelent A. (2015), Kompetencje mediacyjne w profesji pracownika socjalnego, Difin, Warszawa.

Huflejt-Łukasik M. (2010), Zasady etyczne pomocy psychologicznej w psychoterapii i coachingu, [w:] W. Kaczyńska (red.), O etyce stużb społecznych, Instytut Profilaktyki Społecznej i Resocjalizacji Uniwersytetu Warszawskiego, Warszawa, s. 199-210.

Kaczyńska W. (2010), W poszukiwaniu normatywnych i aksjologicznych podstaw etyki niesienia pomocy, [w:] W. Kaczyńska (red.), O etyce służb społecznych, Instytut Profilaktyki Społecznej i Resocjalizacji Uniwersytetu Warszawskiego, Warszawa, s. 305-306.

Kant I. (2001), Uzasadnienie metafizyki moralności, Antyk, Kąty.

Klemensiewicz Z. (1968), O etyce zawodowej nauczyciela akademickiego, „Życie Szkoły Wyższej”, nr 11, 12.

Kotlarska-Michalska A. (2011), Możliwości rozwiąania problemów społecznych poprzez poszerzanie zakresów ról zawodowych pracowników socjalnych, [w:] K. Piątek, K. Szymańska-Zybertowicz (red), Profesjonalna praca socjalna. Nowy paradygmat czy niedokończone zdanie, Wydawnictwo Edukacyjne „Akapit”, Toruń, s. 45-60.

Kudlińska I., Kacprzak A. (2011), Profesjonalna praca socjalna wobec problemu spotecznej bierności i bezradności klientów instytucji pomocowych, [w:] K. Piątek, K. Szymańska-Zybertowicz (red.), Profesjonalna praca socjalna. Nowy paradygmat czy niedokończone zdanie, Wydawnictwo Edukacyjne „Akapit”, Toruń, s. 89-106.

Lazari-Pawłowska I. (1992), Etyki zawodowe jako role społeczne, [w:] I. Lazari-Pawłowska, Etyka. Pisma wybrane, Ossolineum, Wrocław-Warszawa-Kraków, s. 84-91.

Łabieniec P. (2002), Etyka - etyka zawodowa - prawo (zarys problematyki), „Prokurator”, nr 2(10), s. 21-33.

Łuczyńska M. (2010), O odpowiedzialności etycznej pracownika socjalnego, [w:] W. Kaczyńska (red.), O etyce stużb społecznych, Instytut Profilaktyki Społecznej i Resocjalizacji Uniwersytetu Warszawskiego, Warszawa, s. 101-118.

${ }^{10}$ Chodzi o grupę zawodową lub grupę osób z danego zawodu pomocowego, a nie o konkretną osobę. 
Olech A. (2012), Praca socjalna a inne profesje. Punkty styczne i rozłaczne, [w:] M. Rymsza (red.), Pracownicy socjalni i praca socjalna w Polsce. Między stużba społeczna a urzędem, Instytut Spraw Publicznych, Warszawa, s. 331-348.

Olubiński A. (2004), Praca socjalna: Aspekty humanistyczne i pedagogiczne, Wydawnictwo Edukacyjne „Akapit”, Toruń.

Postanowienie Trybunału Konstytucyjnego z 7.10.1992 r. (U 1/92), OTK 1992/2, poz. 38.

Rymsza M. (2016), Jaka profesjonalizacja pracy socjalnej w Polsce i jaki rozwój stużb społecznych?, „Problemy Polityki Społecznej. Studia i Dyskusje”, nr 35(4), s. 25-42, www.problemypolitykispolecznej.pl [dostęp 10.09.2017].

Szmagalski J. (1994), Teoria pracy socjalnej a ideologia i polityka społeczna. Przykład amerykań$s k i$, Wydawnictwo Uniwersytetu Warszawskiego, Warszawa.

Ślipko T. (2004), Deontologia. Jej dzieje i miejsce w systemach etycznych, „Studia Philosophiae Christianae", nr 40(2), s. 83-97.

Tischner J. (1981), Swemu istnieniu zaufać, [w:] J. Tischner, Myślenie według wartości, Społeczny Instytut Wydawniczy „Znak”, Kraków, s. 49.

Zacharzewski K. (2010), Wpływ kodeksów deontologicznych na powstawanie, treść $i$ wykonywanie zobowiazań umownych, [w:] E. Gniewek, K. Górska, P. Machnikowski (red.), Zaciaganie i wykonywanie zobowiazań, C. H. Beck, Warszawa, s. 489-503.

Zacharzew ski K. (2011), Znaczenie kodeksów deontologicznych w dziedzinie prawa prywatnego, „Przegląd Prawa Handlowego”, https://repozytorium.umk.pl/bitstream/handle/item/2843/32. pdf? sequence=1 [dostęp 10.07.2017].

\title{
Strony internetowe
}

http://www.nil.org.pl/_data/assets/pdf_file/0003/4764/Kodeks-Etyki-Lekarskiej.pdf [dostęp 25.06.2017]. http://www.psychoterapia-polska.org/kodeks-etyczny-pfp [dostęp 25.06.2017].

http://www.ptp.org.pl/modules.php?name=News\&file=article\&sid=29 [dostęp 25.06.2017].

https://federacja-socjalnych.pl/images/PDF/kodeks_etyczny.pdf [dostęp: 10.03.2019].

https://ms.gov.pl/Data/Files/_public/mediacje/adr1/kodeksetyczny.pdf [dostęp 25.06.2017].

\section{Beata Kudlińska-Wodo}

\section{DEONTOLOGY OF THE PROFESSIONAL PRACTICE OF THE HELPING PROFESSIONS IN THE LIGHT OF AN ANALYSIS OF CODES OF ETHICS}

\begin{abstract}
Helping professions, professions of public trust are undoubtedly a unique and complex issue due to the importance of the needs and interests of another person - client, beneficiary, pupil or patient - that they fulfill. It seems that a great responsibility is connected with taking some kind of care of - and providing assistance to - an individual who is weaker and thus exposed to farreaching consequences in the form of double social exclusion in case of improper assistance efforts.

The presented article is part of the ongoing, socially important interdisciplinary discussion about the deontology of professional help. The presented analysis of selected codes of ethics provides knowledge about the common features or axiological basics in helping professions, and as a consequence points to the ethical and moral obligations that link the people of public trust in their daily activities.
\end{abstract}

Key words: helping professions, code of ethics, deontology of helping. 